\title{
OCCUPATIONAL HEALTH PROBLEMS OF SAWMILL WORKERS PROCESSING RED PINE IN TURKEY
}

\author{
SÜTÇÜ, A. ${ }^{*}$ - SEMERCI, N. T. \\ Isparta University of Applied Science, Faculty of Forestry, Department of Forest Products \\ Engineering, 32260 Isparta, Turkey \\ (phone: +90-246-2113966; fax: +90-246-2371810) \\ ${ }^{*}$ Corresponding author \\ e-mail: abdullahsutcu@isparta.edu.tr; phone: +90-246-211-3966; fax: +90-246-237-1810 \\ (Received ; accepted )
}

\begin{abstract}
Red pine (Pinus brutia Ten.) is one of the most common and most processed softwood species in the forest products sector in Turkey. It is essential to learn as much information as possible about potential employee health problems that may occur during processing of this wood. For this reason, sawmill workers that produce lumber from the red pine species were investigated in terms of employee health problems. A face-to-face survey method of employees was used to conduct this study. The questionnaire contained three sub-sections: demographic, physical, and environmental and ergonomic factors that affect employee health. The collected data were statistically evaluated and compared with findings from the literature. Certain important findings are presented as crosstabs and graphs for comparison. Based on the study results, employee complaints about the red pine sawing process during working hours are as follows: allergic reactions due to wood dust: $23.2 \%$; burning eyes and redness: $27.4 \%$; dyspnea: $30.5 \%$; prolonged standing and discomfort: $64.9 \%$; noise-induced hearing loss: $38.5 \%$. It is also realized, however, that occupational diseases such as vascular disorders depend not only on the working environment and conditions but also on the age of employees.
\end{abstract}

Keywords: work healthy, woodwork, work-related symptoms, Pinus brutia, occupational hazards

\section{Introduction}

According to a recent press release from the International Council of Forest and Paper Associations (ICFPA), 90\% of wood and paper production comes from 43 countries and the forest products industry has a volume of more than $\$ 470$ billion with more than 14-million people employed worldwide. Approximately 300,000 people provide employment opportunities in Turkey's wood and forestry products industry, with an annual worth of \$19-billion (OAIB, 2017).

However, timber manufacturing in Turkey is a sub-sector of the overall manufacturing sector and consists mainly of private sector enterprises of which the majority are small enterprises that grow slowly. Although there is a total of 10.000 sawmills (small or medium to large) with an annual timber capacity of 10 million $\mathrm{m}^{3}$, at present the current production capacity is reported to be approximately 6-million $\mathrm{m}^{3}$ of sawn timber (Sakarya and Canl1, 2011; Görgün and Unsal, 2015).

However, it has been reported that most wood processing plants are exposed to gas, steam, and wood dust that is harmful to workers, but occupational health has not been given enough importance in these enterprises (Barl1, 1996). In recent years, increased sensitivity to occupational health and diseases has led to a comprehensive review of the lumber and forest products sectors. As a result, international authorities have established some legal arrangements with certain risk groups.

One of the first studies on the subject of health problems in the wood-working industry was conducted in England in 1965. This study established that a critical 
number of workers exposed to furniture and wood dust developed sino-nasal adenocarcinoma. Since then, many scientific studies of employees working in various wood-related industries have been conducted that reported that these types of workers are at risk. It has been reported that beech and oak species are two of the most common species that cause workers to develop some type of disorder, although many other species cause health problems in workers (Demers et al., 1997). It was also reported that quercetin and $\Delta 3$-carene isolated from wood is mutagenic (Jensen et al., 2001).

It was reported that wood dust generated different types of processing could cause work-related respiratory and skin problems or disorders, such as eczema, shortness of breath, nasal cancer, headache, and cramps (Bozkurt and Bozkurt, 1979). It was also reported that workers exposed to high levels of hardwood or softwood dust after smoking and consuming alcohol are at risk for laryngeal cancer (Ramroth et al., 2008). In another study conducted on pine wood sawmills, asthma and cough symptoms were observed for employees that were associated with increased levels of eye and nose irritation resulting from dust exposure (Douwers et al., 2001). It was also proposed that cutting of green wood releases essential oils and monoterpenes into the environment along with wood dust that could cause eye irritation, mucous membrane defects, and skin irritation (Rosenberg et al., 2002). It is clear that dust exposure may result in declining lung function, bronchial hyper-responsiveness, and various other problems such as allergic alveolitis, toxic dust syndrome, chronic bronchitis, rhinitis, mucous irritation, and asthma.

The International Agency for Research on Cancer (IARC) has already classified wood dust as a Group 1 agent that is carcinogenic to humans, based on evidence of the effects of exposure to hardwood dust on the nasal cavities and paranasal sinuses of exposed woodworkers (IARC, 1995). In 2009, the IARC concluded that wood dust should be avoided by workers and could cause cancer of the nasal cavities, paranasal sinuses, and nasopharynx (Siew et al., 2012).

In view of the physical and psychological effects of working conditions in the workplace, it was suggested that musculoskeletal injuries of the upper limbs were the most common type of injury in the timber industry (Jones and Kumar, 2004). Similarly, it was found that the highest rate of injury was associated with the transport of logs to timber processing sites (Bello ve Mijinyawa, 2010). Work-related symptoms in sawmill workers typically are chest tightness, cough, dyspnoea, hoarseness, headache, weakness, sweating, eye and body itching, and skin rash (Dutkiewitcz, 2001).

Based on the results of this comprehensive literature survey, a detailed study focused on the occupational health problems of employees working in red pine processing sawmills was not found. However, the red pine species is spread widely throughout not only Turkey but also throughout the forests of Mediterranean countries. The aim of this research was to evaluate the working conditions of red pine processing sawmills in order to identify general health problems for employees and to develop solutions to problems that may arise in terms of occupational health in depends on the perception of employees. Results of this study will provide simple but high-impact information concerning the quality of life of employees.

\section{Materials and methods}

In this study, health problems that may occur in employees were directly evaluated with a standard questionnaire that was distributed to employees. This survey was given 
to 413 employees across 17 enterprises in Turkey. The study was conducted among sawmill workers processing red pine wood in west mediterrian region between July 2013 and February 2014. The open-ended questions included in the questionnaire form were distributed to employees about 10-15 min. Participants were asked to respond and their opinions about the general problems and their solutions were recorded.

According to a forest activity report from the Union of Chambers and Commodity Exchanges of Turkey (TOBB), 13285 people are employed in the sawmill and parquet sector and $67.3 \%$ of them are workers (8945) (TOBB, 2012). No official information was available that reported the species of wood processed by the sawmills. However, a previous study conducted on the Isparta region found that $90 \%$ of the primary forest production enterprises used red pine (Sütçü et al., 2008).

In order to determine the minimum sample size to be surveyed and to provide statistical reliability, the number of samples needed for a $95 \%$ confidence level was determined to be a minimum of 368 people according to the following equation (Eq. 1$)$ (Krejcie and Morgan, 1970).

$$
s=\frac{X^{2} \mathrm{NP}(1-\mathrm{P})}{\mathrm{d}^{2}(\mathrm{~N}-1)+\mathrm{X}^{2} \mathrm{P}(1-\mathrm{P})}
$$

where; s: required sample size; $\chi^{2}$ : the table value of chi-square for one degree of freedom at the desired confidence level (1.96 $)$; $\mathrm{N}$ : the population size (8945); P: the population proportion (assumed to be 0.5 since this would provide the maximum sample size); d: the degree of accuracy expressed as a proportion (0.05), $s=368$.

In this study, a total of 413 randomly selected people were given the questionnaire in order to produce more accurate results. The study's data information and survey specifications are shown in Table 1.

Table 1. The survey and questionnaire specifications

\begin{tabular}{c|cc|cccc}
\hline \multirow{2}{*}{ Country } & \multicolumn{2}{|c|}{ Population* } & \multicolumn{4}{c}{ Samples } \\
\cline { 2 - 7 } & $\begin{array}{c}\text { Number of work } \\
\text { places (Nw) }\end{array}$ & $\begin{array}{c}\text { Number of } \\
\text { employees } \\
(\mathrm{Ne})\end{array}$ & $\begin{array}{c}\text { Number of } \\
\text { work places } \\
(\mathrm{nw})\end{array}$ & $\begin{array}{c}\text { Number of } \\
\text { employees (ne) }\end{array}$ & $\begin{array}{c}\text { Workplace rate Employees rate } \\
(\mathrm{nw} / \mathrm{Nw})\end{array}$ & $\begin{array}{c}\text { Eme/Ne) } \\
(\mathrm{ne})\end{array}$ \\
\hline Isparta & 402 & 1.070 & 12 & 315 & $2.99 \%$ & $29.44 \%$ \\
Burdur & 235 & 780 & 1 & 15 & $0.43 \%$ & $1.92 \%$ \\
Antalya & 1.027 & 2.496 & 1 & 40 & $0.10 \%$ & $1.60 \%$ \\
Adana & 755 & 1.699 & 3 & 43 & $0.40 \%$ & $2.53 \%$ \\
\hline Total & 2419 & 6045 & 17 & 413 & $0.7 \%$ & $6.83 \%$ \\
\hline
\end{tabular}

* According to TUIK (2007)

The questionnaire forms, which were prepared with the literature reports, contained 23 topics under three headings (demographic, current, physical and environmental factors).

For statistical evaluation of survey data, the necessary analyses were conducted using statistical software SPSS 13.0 and the results of these analyses were interpreted by graphs and tables. Due to the discontinuous data of the study, the results were graded with 0-1 variables that are expressed as discrete variables (yes-no, good-bad, existentnon-existent). Therefore, it was decided to simultaneously use Chi-square for trend test and Student's t-test, assuming $\mathrm{p}<0.05$ as the significance level. However, a Chi-square for trend test was performed whether there was a linear trend for an outcome to increase 
or decrease over the range of an ordered categorical exposure variable (Peat et al., 2009).

\section{Results and discussion}

\section{Evaluation of demographic factors for sawmill employees processing red pine}

Demographic data of the employees in the pine wood processing sawmills are presented in Table 2. According to the survey results, the majority of the employees in the sector are predominately male with an age distribution greater than middle-age. However, according to the Turkish 2002 general manufacturing industry workplace report, the rate of women working in the sub-sector of sawnwood and cork production (excluding furniture) is $6.84 \%$ (TUIK, 2007). In this study, the rate of female employees was found to be only $3.6 \%$. Moreover, more than half of the employees in this sector are in the age group of 30 to 40 years of age. This clearly shows that young people (18-30 years) are not interested in the sawmill industry. It is also important to note that approximately $70 \%$ of employees have primary education while the undergraduate level is not even 1\%. Similar results were found in Turkish studies of the sawmill sector (Osman and Pala, 2009).

Table 2. Demographic characteristics of participants

\begin{tabular}{|c|c|c|c|c|c|}
\hline \multirow{2}{*}{ Gender } & \multicolumn{3}{|c|}{ Female } & \multicolumn{2}{|c|}{ Male } \\
\hline & \multicolumn{2}{|c|}{$\% 3,6$} & \multicolumn{3}{|c|}{$\% 96,4$} \\
\hline \multirow{2}{*}{ Age (Year) } & $<20$ & $20-30$ & 31-40 & $41-50$ & $50<$ \\
\hline & $\% 1$ & $\% 19$ & $\% 50$ & $\% 23$ & $\% 7$ \\
\hline \multirow[t]{2}{*}{ Education level } & Primary Education & High School & \multicolumn{2}{|c|}{ Vocational High School } & $\begin{array}{c}\text { Higher } \\
\text { Education }\end{array}$ \\
\hline & $66.8 \%$ & $14.5 \%$ & \multicolumn{2}{|c|}{$17.9 \%$} & $0.7 \%$ \\
\hline \multirow{2}{*}{\multicolumn{2}{|c|}{ Length of employment (in industry) }} & $<1$ & 2-5 year & 6-10 year & $10<$ \\
\hline & & $\% 13$ & $\% 27$ & $\% 23$ & $\% 37$ \\
\hline
\end{tabular}

It was also found that approximately $40 \%$ of the workers have worked in the same sawmill for 10 years or longer. The work time of employees in the forest products industry also supports the results of our current work (Osman and Pala, 2009). Of the employees in this sector, $45 \%$ had previously worked with furniture or as carpenters and $3 \%$ worked in other manufacturing sectors such as marble-mining, which is different from woodworking sector.

Working units in sawmills are broadly divided into two parts: the sawmill workshopmanufacturing area and sawmill yards. Sawmill workshops refer to the units where activities such as processing, sawing, planning, and sanding are performed and $67 \%$ of employees working in Sawmill workshops. In sawmill yards, activities such as stacking $\operatorname{logs}$, and drying the sawn timber in the open air are performed and $33 \%$ of the employees work in sawmill yards.

\section{Evaluation of physical working comfort for red pine sawmill employees}

Physical working comfort is dependent on the physical working circumstances and the ergonomic characteristics of the manufacturing environment. Conditions such as a poor working environment, noise, inadequate lighting, ventilation, excessive and 
prolonged work hours, absolute temperature and failure to comply with ergonomic standards adversely affects the productivity of employees. However, the most important work environment factors that affect occupational health in the woodworking industry are noise and wood dust (Barl1, 1996). In this study, noise was found to be the most important factor (Figure 1). The main sources of noise in sawmills are band saws, planers, gang saw, and compressors, and the noise level usually exceeds $85 \mathrm{~dB}$ (Reinhold et al., 2006; Gomez et al., 2010). Although this situation may cause temporary deafness and hearing loss, it is reported that this noise is effective even on retention of coronary heart failure and this risk continues even after retirement (Virkkunen et al., 2005). De Souza et al. (2015) claims that noise exposure is independently associated to hypertension. In our study, we considered only for auditory effects. As a result $62 \%$ of the employees stated that they had experienced hearing loss as a result of excessive noise.

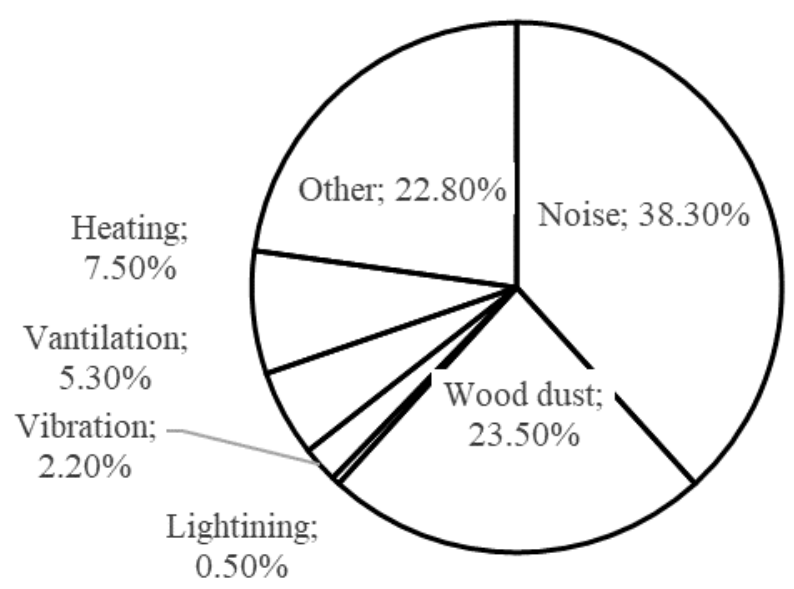

Figure 1. Response of sawmill workers about working conditions

It was reported that the woodwork industry usually utilizes low technology and the average age of many machine-plants is over ten years (Sütçü et.al., 2008; Sakarya and Canl1, 2011). The use of old machinery and facilities deprives the sector of new technologies that have taken the necessary measures in terms of the health and safety of employees. As a result of the observations made within the scope of the evaluated enterprises, significant differences in noise and vibration between the use of old and new technology, especially with compressor, multi-slitting, and profile machines, were observed. Ülker (2018) reported that, in furniture manufacturing, most of the machines exceed the threshold of $85 \mathrm{~dB}$, even when operating in the idle position. Vibration, as a noise factor, causes pain in various limbs (e.g., wrist, arm, elbow, leg) of the workers. Pain was reported in the body as a result of exposure to vibration in 60.3 percent of employees.

Another important factor is 'wood dust' (with a rate of about 24\%), as shown in Figure 1. Wood dust is known to cause respiratory symptoms related to asthma, dermatitis, eye irritation, and upper respiratory tract. However, wood dust is also classified as a human carcinogen by IARC (IARC, 1995). And it has only been conclusively linked to sinonasal cancers, despite individual studies suggesting an association with a range of respiratory tract cancers. Hancock et al. (2014) has 
demonstrated significant associations between lung cancer and wood dust exposure or employment in wood dust-related occupations. Moreover, respiratory protective equipment and local exhaust ventilation reduce the risk of occupational sinonasal cancer (Emanuelli et al., 2016).

Lighting and ventilation are important working condition factors. Adequate levels of lighting reduces the risk of accidents that may occur when using machinery and equipment. According to this study, the lighting situation is considered to be sufficient by a high percentage of employees $(91.5 \%)$. However, ventilation conditions were not quite as high by those employees who considered the lighting conditions to be adequate $(84.3 \%)$.

Temperature and humidity conditions are other important factors that affect the subjective feeling of human comfort. Too low or too high ambient temperature and high humidity negatively affect the productivity of employees. Based on the results of our study, although the majority of the employees thought that thermal comfort was adequate in the winter and summer months, approximately $40 \%$ of them reported that they felt very hot or very cold in terms of thermal comfort. This indicates that enterprises do not take adequate measures for heating in cold areas and cooling in hot areas. In regions with cold winter conditions, such as Isparta, experienced warming problems due to the lack of adequate heating systems in the facility; warm regions, such as Adana, due to the heat and humidity in summer conditions, climatic disturbance is felt. Despite this, the ratio of those who feel that thermal comfort is sufficient $(62 \%)$ should not be underestimated.

\section{Evaluation of general health problems in sawmill activities}

In the forest product industry, it is inevitable for employees to avoid joint disturbances as a result of long-term outpatient work, loading and unloading of loggers, transporting large and heavy materials between machines, and loading the machine. But this factor can cause work related musculoskeletal syndrome disorders (MSD's) or different kinds of problems in organisms (Gedik and Akyüz, 2004). However, it was proposed that low back pain, tendonitis, and tenosynovitis are the most common MSD's that accounted for 25\% of occupational injuries in the United States in 1997 (Wu et al., 2009). Bello and Mijinyawa (2010) reported that 57.81\% of those working in the sawmill industry in Nigeria had pain in the back and in the lower back. According to our findings as summarized in Table 3, the number and incidence of joint pain (back, waist, foot) caused by prolonged standing during work has been quite high (64.9\%). Also, the situation of vascular diseases that has emerged as an occupational discomfort due to prolonged standing during work conducted by sawmill workers.

Table 3. Symptoms to body area for sawmill tasks

\begin{tabular}{|c|c|c|}
\hline Symptoms $(n=413)$ & Frequency & Percentage (\%) \\
\hline Work Related Musculoskeletal Syndrome Disorders (MSD's) & 268 & 64.9 \\
\hline Joint pain due to vibratory & 164 & 39.7 \\
\hline Hearing Impairment & 159 & 38.5 \\
\hline Respiratory dysfunction (dyspnea) & 126 & 30.5 \\
\hline Eye irritation due to wood dust & 113 & 27.4 \\
\hline Varicose veins & 106 & 25.7 \\
\hline Work related allergic reactions & 96 & 23.2 \\
\hline
\end{tabular}


The distribution of vascular disease in the participants according to demographic characteristics is shown in Table 4. The incidence of vascular disease was not significantly different according to gender and work unit $(\mathrm{p}>0.005)$. Although there was a decrease in the trend of educational status $(26.8 \% ; 23.9 \% ; 0.0 \%)$, the incidence of vascular disease was not significantly different based on the education level of the employees $\left(\chi^{2}\right.$ for trend $=$ $0.820, \mathrm{p}=0.365$, Table 4). According to the data evaluated and the statements of the employees participating in the survey, a significant difference was found between vocational education and vascular disease $\left(\chi^{2}\right.$ for trend $\left.=24.294, p=0.0001\right)$. Although the frequency of vascular disturbance based on length of employment showed a significant difference, the results of the analysis $\left(\chi^{2}\right.$ for trend $\left.=10.304, p=0.005\right)$ show that, when the direction of the trend is taken into consideration and employees with 6-10 years of experience are excluded from the evaluation, the significant difference in the analysis is lost $\left(\chi^{2}\right.$ for trend $\left.=4.42, p=0.110\right)$. This situation applies to employees who work in the red pine processing sawmills and shows that the length of employment has no effect on the risk of vascular disease.

Based on the t-test, the relative age of patients that developed vascular disease was older than no patients, but the difference was not significant (37.3, SD:7.58; 36.6, SD:4.7; $\mathrm{p}=0.428)$.

The incidence of MSD's was not significantly different based on gender, educational status, and occupational education ( $\mathrm{p}>0.05$, Table 4). However, the relationship of MSD's with the working area showed a significant difference $\left(\chi^{2}=3.426, \mathrm{p}<0.05\right)$. This indicates that workers $(71.1 \%)$ in the yards face more risk of joint pain than those working in the workshop (61.9\%).

According to the length of employment, the incidence of MSD's showed a significant difference $\left(\chi^{2}\right.$ for trend $=11.374, p<0.05$, Table 4). However, when employees with a work duration less than one year were excluded from the evaluation, the significant difference in the analysis was lost $\left(\chi^{2}\right.$ for trend $\left.=4.66, p=0.097\right)$. According to the results of the analysis, workers with a work duration of less than one year had many complaints about MSD's (80.8\%). Although there is a gradual increase in length of employment of more than one year, no significant difference was observed based on the results of the analysis, but this situation can be explained by the "training and practice" effect (Y1ldırım, 1989).

Workers in woodwork industries are exposed to hand-arm vibrations, awkward posture, repetitive tasks, and high grip force. Also, vibration has been reported to introduce fatigue in muscles, further augmenting postural stress (Bhardwaj and Khan, 2018). In this study, the change in the occurrence of MSD's (especially joint pain) caused by demographicbased vibration exposure is shown in Table 4.

Joint pain caused by vibration and its correlation to gender, working unit, and work time does not show a significant difference. However, there is a significant difference based on the education level of the employees $\left(\chi^{2}\right.$ for trend $=5.683, p<0.05$, Table 4$)$. Based on the occupational education of employees, the presence of joint pain caused by exposure to vibration showed a significant difference $\left(\chi^{2}=8.077, \mathrm{p}<0.05\right)$. However, the mean age (35.7; SD:8.0) of participants with complaints about joint pain resulting from exposure to vibration was lower than the mean age of those without joint pain (37.5; SD:7.6, $p<0.05)$. As a result of these observations made in sawmills, the employment of highly qualified personnel with a higher education level in more qualified jobs, low level of education, new entry into the business and unqualified personnel can be related to the work in units of older model machines, which work more noisily and vibrate. 
Table 4. The Crosstab about relationship with Symptoms for sawmill employees processing red pine according to demographic characteristics

\begin{tabular}{|c|c|c|c|c|c|c|c|c|c|c|c|c|c|c|c|}
\hline \multirow{3}{*}{ Symptoms } & \multirow{2}{*}{\multicolumn{2}{|c|}{$\begin{array}{c}\text { Demog-raphic } \\
\text { Characters }\end{array}$}} & \multicolumn{2}{|c|}{ Gender } & \multicolumn{3}{|c|}{ Education level } & \multicolumn{2}{|c|}{ Voc. Education } & \multicolumn{2}{|c|}{ Production area } & \multicolumn{4}{|c|}{ Length of Employment } \\
\hline & & & Female & Male & Pri. Edu & H. Sch. & H. Edu. & Yes & No & Work-shop & Yards & $<1$ & $2-5$ year & 6-10 year & $10<$ \\
\hline & & Count & 15 & 398 & 276 & 134 & 3 & 105 & 308 & 278 & 135 & 52 & 111 & 97 & 153 \\
\hline \multirow{6}{*}{$\begin{array}{l}\text { Varicose } \\
\text { veins }\end{array}$} & \multirow{2}{*}{ Yes } & Count & 1 & 105 & 74 & 32 & 0 & 46 & 60 & 75 & 31 & 12 & 26 & 16 & 52 \\
\hline & & $\%$ & 6.7 & 26.4 & 26.8 & 23.9 & 0 & 43.8 & 19.5 & 27 & 23 & 23.1 & 23.4 & 16.5 & 34 \\
\hline & \multirow{2}{*}{ No } & Count & 14 & 293 & 202 & 102 & 3 & 59 & 248 & 203 & 104 & 40 & 85 & 81 & 101 \\
\hline & & $\%$ & 93.3 & 73.6 & 73.2 & 76.1 & 100 & 56.2 & 80.5 & 73 & 77 & 76.9 & 76.6 & 83.5 & 66 \\
\hline & & $\chi^{2}$ & \multicolumn{2}{|c|}{2.945} & \multicolumn{3}{|c|}{0.82} & \multicolumn{2}{|c|}{24.294} & \multicolumn{2}{|c|}{0.768} & \multicolumn{4}{|c|}{0.768} \\
\hline & & $p$ & \multicolumn{2}{|c|}{0.069} & \multicolumn{3}{|c|}{0.365} & \multicolumn{2}{|c|}{0.0001} & \multicolumn{2}{|c|}{0.226} & \multicolumn{4}{|c|}{0.226} \\
\hline \multirow{6}{*}{$\begin{array}{l}\text { Arthrosis } \\
\text { Pain }\end{array}$} & \multirow{2}{*}{ Yes } & Count & 8 & 260 & 174 & 93 & 1 & 64 & 204 & 172 & 96 & 42 & 61 & 61 & 104 \\
\hline & & $\%$ & 53.3 & 65.3 & 63 & 69.4 & 33.3 & 61 & 66.2 & 61.9 & 71.1 & 80.8 & 55 & 62.9 & 68 \\
\hline & \multirow{2}{*}{ No } & Count & 7 & 138 & 102 & 41 & 2 & 41 & 104 & 106 & 39 & 10 & 50 & 36 & 49 \\
\hline & & $\%$ & 46.7 & 34.7 & 37 & 30.6 & 66.7 & 39 & 33.8 & 38.1 & 28.9 & 19.2 & 45 & 37.1 & 32 \\
\hline & & $\chi^{2}$ & \multicolumn{2}{|c|}{0.811} & \multicolumn{3}{|c|}{16.679} & \multicolumn{2}{|c|}{2.144} & \multicolumn{2}{|c|}{2.41} & \multicolumn{4}{|c|}{2.669} \\
\hline & & $p$ & & & & 0.0001 & & & & 0.0 & & & & .445 & \\
\hline & Yeo & Count & 3 & 123 & 102 & 23 & 1 & 38 & 88 & 38 & 88 & 15 & 40 & 30 & 41 \\
\hline & Yes & $\%$ & 20 & 30.9 & 37 & 17.2 & 33.3 & 36.2 & 28.6 & 36.2 & 28.6 & 28.8 & 36 & 30.9 & 26.8 \\
\hline Respiratory & & Count & 12 & 275 & 174 & 111 & 2 & 67 & 220 & 67 & 220 & 37 & 71 & 67 & 112 \\
\hline dysfunction & No & $\%$ & 80 & 69.1 & 63 & 82.8 & 66.7 & 63.8 & 71.4 & 63.8 & 71.4 & 71.2 & 64 & 69.1 & 73.2 \\
\hline & & $\chi^{2}$ & & & & 16.679 & & & & 2.4 & & & & 669 & \\
\hline & & $p$ & & & & 0.0001 & & & & 0.0 & & & & .445 & \\
\hline & & Count & 4 & 92 & 66 & 30 & 0 & 28 & 68 & 63 & 33 & 21 & 20 & 20 & 35 \\
\hline & Yes & $\%$ & 26.7 & 23.1 & 23.9 & 22.4 & 0 & 26.7 & 22.1 & 22.7 & 24.4 & 40.4 & 18 & 20.6 & 22.9 \\
\hline Work related & & Count & 11 & 306 & 210 & 104 & 3 & 77 & 240 & 215 & 102 & 31 & 91 & 77 & 118 \\
\hline $\begin{array}{l}\text { allergic } \\
\text { reactions }\end{array}$ & No & $\%$ & 73.3 & 76.9 & 76.1 & 77.6 & 100 & 73.3 & 77.9 & 77.3 & 75.6 & 59.6 & 82 & 79.4 & 77.1 \\
\hline & & $\chi^{2}$ & & & & 0.367 & & & & 0.1 & & & & 0.649 & \\
\hline & & $p$ & & & & 0.545 & & & & 0.3 & & & & .014 & \\
\hline
\end{tabular}




\begin{tabular}{|c|c|c|c|c|c|c|c|c|c|c|c|c|c|c|c|}
\hline \multirow{3}{*}{ Symptoms } & \multirow{2}{*}{\multicolumn{2}{|c|}{$\begin{array}{c}\text { Demog-raphic } \\
\text { Characters }\end{array}$}} & \multicolumn{2}{|c|}{ Gender } & \multicolumn{3}{|c|}{ Education level } & \multicolumn{2}{|c|}{ Voc. Education } & \multicolumn{2}{|c|}{ Production area } & \multicolumn{4}{|c|}{ Length of Employment } \\
\hline & & & Female & Male & Pri. Edu & H. Sch. & H. Edu. & Yes & No & Work-shop & Yards & $<1$ & $2-5$ year & 6-10 year & $10<$ \\
\hline & & Count & 15 & 398 & 276 & 134 & 3 & 105 & 308 & 278 & 135 & 52 & 111 & 97 & 153 \\
\hline \multirow{6}{*}{$\begin{array}{l}\text { Eye irritation } \\
\text { due to wood } \\
\text { dust }\end{array}$} & \multirow{2}{*}{ Yes } & Count & 5 & 108 & 85 & 28 & 0 & 26 & 87 & 70 & 43 & 18 & 33 & 33 & 29 \\
\hline & & $\%$ & 33.3 & 27.1 & 30.8 & 20.9 & 0 & 24.8 & 28.2 & 25.2 & 32.9 & 34.6 & 29.7 & 34 & 19 \\
\hline & \multirow{3}{*}{ No } & Count & 10 & 290 & 191 & 106 & 3 & 79 & 221 & 208 & 92 & 34 & 78 & 64 & 124 \\
\hline & & $\%$ & 66.7 & 72.9 & 69.2 & 79.1 & 100 & 75.2 & 71.8 & 74.8 & 68.1 & 65.4 & 70.3 & 66 & 81 \\
\hline & & $\chi^{2}$ & \multicolumn{2}{|c|}{0.279} & \multicolumn{3}{|c|}{5.409} & \multicolumn{2}{|c|}{0.478} & \multicolumn{2}{|c|}{2.035} & \multicolumn{4}{|c|}{9.295} \\
\hline & & $p$ & \multicolumn{2}{|c|}{0.393} & \multicolumn{3}{|c|}{0.02} & \multicolumn{2}{|c|}{0.288} & \multicolumn{2}{|c|}{0.096} & \multicolumn{4}{|c|}{0.026} \\
\hline \multirow{6}{*}{$\begin{array}{c}\text { Hearing } \\
\text { Impairments }\end{array}$} & \multirow{2}{*}{ Yes } & Count & 2 & 157 & 109 & 50 & 0 & 39 & 120 & 100 & 59 & 26 & 44 & 38 & 51 \\
\hline & & $\%$ & 13.3 & 39.4 & 39.5 & 37.3 & 0 & 37.1 & 39 & 36 & 43.7 & 50 & 39.6 & 39.2 & 33.3 \\
\hline & \multirow{2}{*}{ No } & Count & 13 & 241 & 167 & 84 & 3 & 66 & 188 & 178 & 76 & 26 & 67 & 59 & 102 \\
\hline & & $\%$ & 86.7 & 60.6 & 60.5 & 62.7 & 100 & 62.9 & 61 & 64 & 56.3 & 50 & 60.4 & 60.8 & 66.7 \\
\hline & & $\chi^{2}$ & \multicolumn{2}{|c|}{4.163} & \multicolumn{3}{|c|}{0.65} & \multicolumn{2}{|c|}{0.109} & \multicolumn{2}{|c|}{2.295} & \multicolumn{4}{|c|}{4.709} \\
\hline & & $p$ & \multicolumn{2}{|c|}{0.033} & \multicolumn{3}{|c|}{0.42} & \multicolumn{2}{|c|}{0.417} & 0.0 & & & & .194 & \\
\hline & Ye & Count & 3 & 161 & 120 & 44 & 0 & 54 & 110 & 111 & 53 & 27 & 42 & 30 & 65 \\
\hline & Yes & $\%$ & 20 & 40.5 & 43.5 & 32.8 & 0 & 51.4 & 35.7 & 39.9 & 39.3 & 51.9 & 37.8 & 30.9 & 42.5 \\
\hline Joint pain & & Count & 12 & 237 & 156 & 90 & 3 & 51 & 198 & 167 & 82 & 25 & 69 & 67 & 88 \\
\hline $\begin{array}{l}\text { caused by } \\
\text { vibration }\end{array}$ & No & $\%$ & 80 & 59.5 & 56.5 & 67.2 & 100 & 48.6 & 64.3 & 60.1 & 60.7 & 48.1 & 62.2 & 69.1 & 57.5 \\
\hline & & $\chi^{2}$ & & & & 5.683 & & & & 0.0 & & & & .019 & \\
\hline & & $p$ & & & & 0.017 & & & & 0.4 & & & & .071 & \\
\hline
\end{tabular}

Abbreviations: Voc. Education :Vocational Education; Pri. Edu.: Primary Education (basic education for eight years); H. Sch.: High School (4 years of High School); H.Edu.: Higher Education (4 years of University and upper) 
Wood dust is one of the most important health risks in forest product workplaces, as described in the literature. Required limit values have been established by international organizations (Siew et al., 2012; IARC, 2012). However, the mechanism of pathogenesis involving the lungs in woodworkers could be due to exposure to airborne dust of different particle sizes, concentrations and compositions.

Moreover, these structural components are also responsible for most toxic, irritant, and sensitizing effects which become a cause of impairment and worsening of lung function. In addition, it is well known that wood contains many microorganisms (including fungi) and toxins, agents such as; terpenes, abietic acid, and plicatic acid in different types are, potentially, implicated in the occurrence of asthma by inducing increased bronchial responsiveness or by damaging the bronchial epithelial cells (Kherde et al., 2017). According to the results of the survey, 30\% of the workers experienced dyspnea that was caused by exposure to wood dust. Table 4 illustrates the change in dyspnea frequency caused by participants' exposure to wood dust based on demographic characteristics. The frequency of dyspnea was not significantly different according to gender, occupational education, work unit, and work time. But it was significantly different based on education level of employees $\left(\chi^{2}\right.$ for trend $=1.679$, $\mathrm{p}=0.0001$ ). This situation can be explained by qualified personnel that graduated from high school working in more qualified work units (technical units-departments which are less exposed to wood dust). When the ratio of university graduates contrasts with the above explanation, only three university graduates participated in the survey, which makes it difficult to propose a valid interpretation.

There was no statistically significant difference $(p>0,05)$ in the mean age between employees who have shortness of breath (37.1; SD:7.3) and those that do not (36.6; SD:8.0).

The frequency of allergic reactions did not show a significant difference based on gender, education, occupational education status, and working area (Table 4). The frequency of allergic reactions based on length of employment showed a significant difference $\left(\chi^{2}\right.$ for trend $\left.=10.649, p<0,05\right)$. This difference is due to the frequency of high allergic reactions in less than one year (40.4\%). When employees less than one year are excluded from the evaluation, the significant difference is lost $\left(\chi^{2}\right.$ for trend $=$ $0.92, \mathrm{p}>0,05)$.

The mean age (35.4, SD:7.5) of participants having allergic reactions was lower than the mean age of participants without allergic reactions (37.2, SD:7.8; $p=0.051)$. As a result of exposure to dust in the workplace, $27.4 \%$ of the workers had itching, redness, and burning in the eyes caused by wood dust but $72.6 \%$ of the participants did not have such complaints (Table 4). In the literature, allergic reactions to sawdust from softwood are more common among sawmill workers than allergic reactions to sawdust from hardwood (Dutkiewicz, 2001). Rosenberg et al. (2002) reported for pine processing industries the focused on monoterpene exposure which causes work-related subjective symptoms.

There was no significant difference in the occurrence of redness and burning in the eyes based on gender, the level of vocational education, and the work area (Table 4). A significant difference was observed based the education level of the employees $\left(\chi^{2}\right.$ for trend $=5.490, p<0.05)$. Similarly, a significant difference was observed based on length of employment $\left(\chi^{2}\right.$ for trend $\left.=9.295, \mathrm{p}<0.05\right)$. This difference was due to redness and burning complaints ranging from 6 to 10 years $(34 \%)$. When these employees are excluded from the evaluation, the significant difference is lost $\left(\chi^{2}\right.$ for trend $=0.59$, 
$\mathrm{p}>0.05)$. The mean age (35.3, SD:6.4) of the participants that have redness and burning in the eyes was lower than the mean age of the participants without these complaints (37.3, SD:8.8; $\mathrm{p}=0.051)$.

The percentage of participants who stated that they experienced hearing loss as a result of exposure to noise in the red pine processing sawmill was high $(38.5 \%$, Table $3)$. The frequency of hearing loss based on gender showed a significant difference $(\chi 2=4.163, \mathrm{p}=0.033)$. Male employees $(39.4 \%)$ expressed that they experienced hearing loss due to more noise so than women. Male employees are exposed to greater levels of noise depend on working in noise-intensive environments and may experience more health problems related to hearing loss. Female are generally employed in classification-standardization and packaging units. In addition, no significant difference was found in terms of hearing loss status based on education level, vocational education, working area, and length of employment. Similarly, there was no significant difference in the $95 \%$ confidence level between the average age of the participants with hearing loss and the mean age of those who did not experience hearing loss $(p=0.167)$. According to Table 4, the rate of hearing loss was found to be as high as $50 \%$ in employees with less than one year of work experience. However, it is known that at least two years of working in a noisy environment are required for the formation of hearing loss as a result of continuous noise exposure. According to these data, it is estimated that the employees experience temporary hearing loss.

\section{General complaints about ergonomic conditions in red pine processing sawmills}

Figure 2 shows a summary for the question of 'What do you think is the most important factor that negatively affects the health of employees in the environment where you work?' The most important complaints expressed by workers were "ignore use of personal protective equipment (PPE)" and "overtime work".

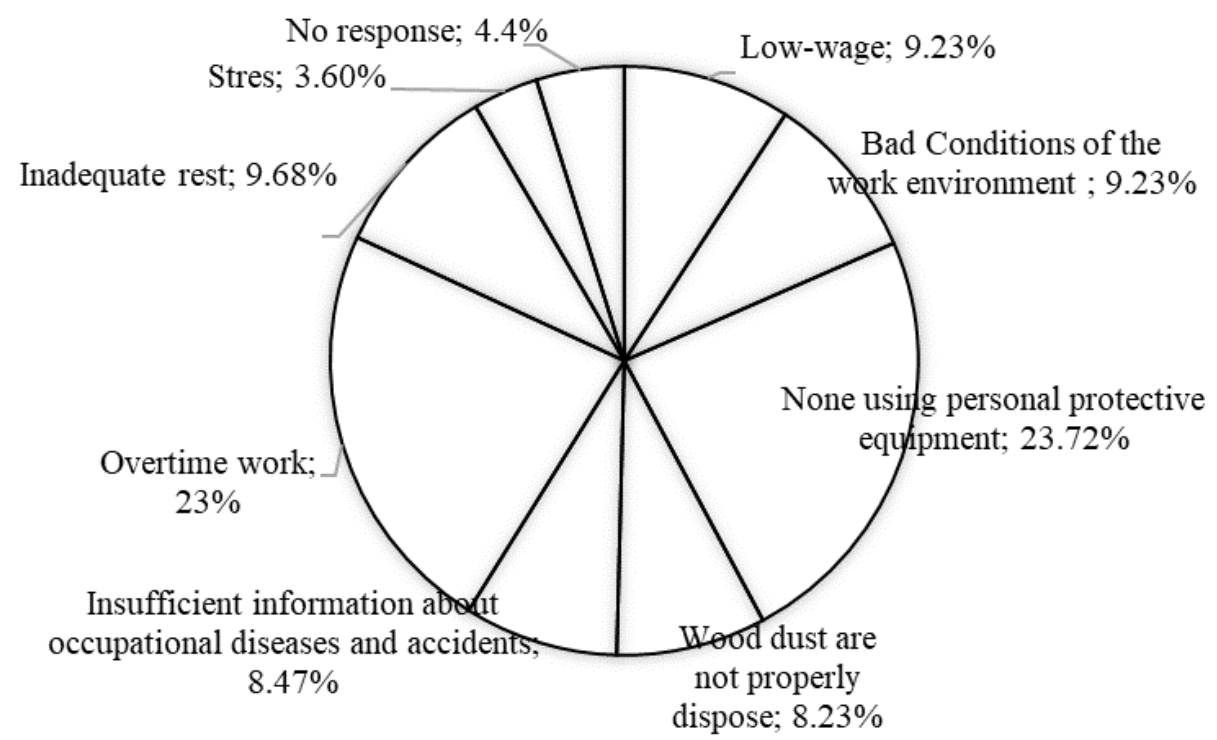

Figure 2. Complaints in red pine processing sawmills expressed by workers

It is understood that the use of PPE, such as earmuffs or plugs, hand gloves, or masks, has been poor and inappropriate in the wood processing industries and they are 
often considered to be irrelevant and disturbing. According to the results of the survey; approximately $25 \%$ of employees complain of non-use of PPE in the work environment. One of the most common reason for not using it, was mentioned that PPE causes discomfort while working (Top et al., 2016). Effendi and Pratama (2017) found a significant relationship between knowledge with the use of personal protective equipment. Similar findings were made by other groups (Bello and Mijinyawa, 2010; Jerie, 2012). These groups also reported that some workers $(23 \%)$ complained about overtime. However, the majority of these employees are ungrudging in to work under the overtime work to meet their economic requirements due to their unqualified employee status and minimum wage. In Turkey, according to the Regulation on Working Hours of Labor Law, uninterrupted work time cannot exceed 11 hours per day (RG, 25425). Overtime work causes problems such as fatigue, weariness, and carelessness in employees and also decreases job dissatisfaction and work performance. This is why the risk of accidents can be reduced while increasing employee motivation and work efficiency with organizational configuration measures such as more efficient organization of break times, job expansion, and job enrichment. In addition, 9\% of employees reported that they do not have any information or knowledge about occupational health and safety. This shows that the risks to employees in the work environment, the hazards that may arise from these risks, and the rights of employees against these risks are not known. In this scenario, employers have a significant role. Employers should organize information seminars for their employees through their occupational health and safety experts. The studies done by various authors have also recommended implementation of an occupational health service and development of a means for collective and individual prevention to reduce the risk maximally. It has already proposed that the health risk should be minimized by the mutual collaboration between health officials, woodworkers and their management (Kherde et al., 2016).

\section{Conclusions}

The employees studied in this work are exposed to wood dust generated during the processing of red pine wood, to chemicals formed by the extracts and essential oils in the wood, and to hazardous preservatives that are used to prevent biological and physical degradation of these raw materials. In addition, it is inevitable that occupational health problems will be experienced by the employees due to the fact that working conditions are not sufficiently ergonomic, heavy material is manipulated manually, and physical factors such as overtime work.

However, inevitable muscular and skeletal syndrome disorders develop as a result of prolonged standing during work, loading and unloading of loggers, transportation of large and heavy planks between the machines. However, workers in the yards encounter more risk of joint pain than those working in the workshop. In addition, use of PPE, improvements to the working environment, and organization of information seminars about occupational health and safety have been suggested by workers.

The length of the work day causes problems such as fatigue, weariness, absence, turnover, carelessness, poor performance, and decreased job satisfaction. For these reasons, the risk of accidents can be reduced while implementing work structuring principles such as more effective organization of break times, job enrichment, job enlargement, and job rotation to increase motivation and work efficiency. 
Acknowledgements. This study is derived from Nazik Tugba Semerci's MSc Thesis. The authors wish to thank the Suleyman Demirel University, Scientific Research Projects Coordination Unit (SDU-BAP) Project number: 3559-YL1-13 for the financial support received for this research.

\section{REFERENCES}

[1] Barl1, Ö. (1996): Physical Environment Factors That Influence Human Health in Forest Product Industry. - Tr. J. of Agriculture and Forestry 22: 521-524. (in Turkish).

[2] Bello, R. S., Mijinyawa, Y. (2010): Assessment Of Injuries in Small Scale Sawmill Industry of South Western Nigeria. - Agric Eng Int: CIGR Journal 12(1): 151-157.

[3] Bhardwaj, S., Khan, A. A. (2018): Ergonomics investigation for orientation of the handles of wood routers. - International Journal of Occupational Safety and Ergonomics (JOSE) 24(4): 592-604.

[4] Bozkurt, A. Y., Bozkurt, T. (1979): Healthy problems in woodworking industries. Journal of the Faculty of Forestry Istanbul University, Series B 29(2): 60-67. (in Turkish).

[5] Demers, P., Teschke, K., Kennedy, S. (1997): What to Do About Softwood? A Review of Respiratory Effects and Recommendations Regarding Exposure Limits. - American Journal of Industrial Medicine 31: 385-398.

[6] De Souza, T. C. F., Périssé, A. R. S., Moura, M. (2015): Noise exposure and hypertension: Investigation of a silent relationship Environmental and occupational health. - BMC Public Health 15(1): 328.

[7] Douwes, J., McLean, D., Slater, T., Pearce, N. (2001): Asthma and Other Respiratory Symptoms in New Zealand Pine Processing Sawmill Workers. - American Journal of Industrial Medicine 39(6): 608-615.

[8] Dutkiewicz, J., Skorska, C., Krysinska-Traczyk, E., Dutkiewicz, E., Matuszyk, A., Sitkowska, J. (2001): Response of Sawmill Workers to Work-Related Airborne Allergens. - Ann Agric Environ Med 8(1): 81-90.

[9] Effendi, L., Pratama, A. P. (2017): Factors Related For Use Of Personal Protective Equipment on Worker Carpenter in Ciputat District South Tangerang City Bante. International Conference of Occupational Health and Safety (ICOHS) 2017, Proceeding Book, 1-2 Nov. 2017, Bali, Indonesia, FKM UI, Depok, pp.113-123.

[10] Emanuelli, E., Alexandre, E., Cazzador, D., Comiati, V., Volo, T., Zanon, A., Scapellato, M. L., Carrieri, M., Martini, A., Mastrangelo, G. (2016): A case-case study on sinonasal cancer prevention: effect from dust reduction in woodworking and risk of mastic/solvents in shoemaking. - Journal of Occupational Medicine \& Toxicology 11(1): 1-7.

[11] Gedik, T., Akyüz, İ. (2004): Investigation of working conditions based on sectors. Kafkas Üniversitesi Artvin Orman Fakültesi Dergisi 5(2): 182-192. (in Turkish).

[12] Gomez, M. E., Sanchez, J. F., Cardona, M. A., Pioquinto, J. F., Torres, P., Sanchez, D., Camargo, L. M., Castaneda, R. A., Villamizar, R. H., Cremades, V. L. (2010): Health and Working Conditions in Carpenter's Workshop in Armenia (Colombia). - Industrial Health 48(2): 222-230.

[13] Görgün, H. V., Ünsal, Ö. (2015): Past, present and future of the lumber industry in Turkey. - 2023'e Doğru 3. Doğa ve Ormancılık Sempozyumu, Antalya, Türkiye. pp.1-1. (in Turkish).

[14] Hancock, D. G., Langley, M. E., Chia, K. L., Woodman, R. J., Shanahan, E. M. (2015): Wood dust exposure and lung cancer risk:a meta-analysis. - Occup Environ Med 72: 889898.

[15] IARC. (1995): IARC Monographs on the Evaluation of Carcinogenic Risks to Humans: Wood Dust and Formaldehyde. - Vol. 62. Lyon, France: IARC, World Health Organization.

[16] IARC. (2012): IARC Monographs on the Evaluation of Carcinogenic Risks to Humans: Wood Dust. - Vol. 100C [Online], https://monographs.iarc.fr [accessed 02 Dec., 2018]. 
[17] Jensen, L. K., Larsen, A., MØlhave, L., Hansen, M. G., Knudsen, B. (2001): Health Evaluation of Volatile Organic Compound (VOC) Emissions from Wood and WoodBased Materials. - Archives of Environmental Health: An International Journal 56(5): 419-432.

[18] Jerie, S. (2012): Occupational health and safety problems among workers in the wood processing industries in Mutare, Zimbabwe. - Journal of Emerging Trends in Economics and Management Sciences (JETEMS) 3(3): 278-285.

[19] Jones, T., Kumar, S. (2004): Occupational Injuries and Illnesses in The Sawmill Industry of Alberta. - International Journal of Industrial Ergonomics 33: 415-427.

[20] Kherde, P. M., Mishra, N. V., Chitta, S. S., Gahukar, S. D. (2017): Influence of sawdust on peak expiratory flow rate in sawmill workers of central India working in unprotected environment and its correlation with duration of exposure. - National Journal of Physiology, Pharmacy and Pharmacology 7(1): 68-73.

[21] Krejcie, R. V., Morgan, D. W. (1970): Determining Sample Size for Research Activities. - Educational and Psychological Measurement 30: 607-610.

[22] OAIB. (2017): Development of Foreign Trade in Turkey, Wood, Paper and Forest Products Sector Report. - www.turkishwood.org [accessed 24 Dec., 2018] (in Turkish).

[23] Osman, E., Pala, K. (2009): Occupational Exposure to Wood Dust and Health Effects on the Respiratory System in a Minor Industrial Estate in Bursa/Turkey. - International Journal of Occupational Medicine and Environmental Health 22(1): 43-50.

[24] Peat, J., Barton, B., Elliott, E. (2009): Statistics Workbook for Evidence-based Health Care. - Chichester: Wiley-Blackwell.

[25] Ramroth, H., Dietz, A., Ahrens, W., Bechen, H. (2008): Occupational Wood Dust Exposure and the Risk of Laryngeal Cancer: A Population Based Case-Control Study in Germany. - American Journal of Industrial Medicine 51(9): 648-655.

[26] Reinhold, K., Tint, P., Kiivet, G. (2006): Risk Assessment In Textile And Wood Processing Industry. - International Journal of Reliability, Quality and Safety Engineering 13(2): 115-125.

[27] RG 25425. (2004): Regulation on working time related to labor law. - Resmi Gazete, (2004, 6 April) (in Turkish).

[28] Rosenberg, C., Liukkonen, T., Kallas-Tarpila, T., Ruonakangas, A., Ranta, R., Nurminen, M., Welling, I., JaÈppinen, P. (2002): Monoterpene and Wood Dust Exposures: WorkRelated Symptoms Among Finnish Sawmill Workers. - American Journal of Industrial Medicine 41(1): 38-53.

[29] Sakarya, S., Canl1, Ş. (2011): Lumber Report [Online]. - Central Anatolian Furniture, Paper and Forestry Products Exporters' Union, www.turkishwood.org [accessed 05 May, 2013] (in Turkish).

[30] Semerci, N. T. (2014): Occupational health problems in red pine (pinus brutia) processing sawmills. - MSc Thesis, Suleyman Demirel University, Isparta, Turkey (in Turkish).

[31] Siew, S. S., Kauppinen, T., Kyyrönen, P., Heikkilä, P., Pukkala, E. (2012): Occupational exposure to wood dust and formaldehyde and risk of nasal, nasopharyngeal, and lung cancer among Finnish men. - Cancer Manag Res. 4: 223-232.

[32] Sütçü, A., Keskin, H., Demirgil, H., Sezgin, A., Dulupçu, M. A., Karakuş, B., Demirel, O., Şentürk, C., Çakmakçı, H. A. (2008): Investigation on Forest Products Industry in Isparta. - Isparta Governorship Provincial Directorate of Industry and Trade, Isparta, Turkey (in Turkish).

[33] TOBB. (2012): Sectoral Report of Turkish Forestry Products Council 2011. - The Union of Chambers and Commodity Exchanges of Turkey (TOBB) [Online], www.tobb.org.tr [accessed 04 Jan., 2013] (in Turkish).

[34] Top, Y., Adanur, H., Öz, M. (2016): Comparison of practices related to occupational health and safety in microscale wood-product enterprises. - Safety Science 82: 374-381. 
[35] TUIK. (2007): General Census of Industry and Business Local Units Provinces 2002. Turkish Statistical Institute, Printing Division, Ankara,Turkey.

[36] Ülker, O. (2018): Investigation of Noise Exposure at Furniture Production and Analyzing Noise Levels. - International Journal of Engineering Research and Development 10(2): 225-244. (in Turkish).

[37] Virkkunen, H., Kauppinen, T., Tenkanen, L. (2005): Long-term effect of occupational noise on the risk of coronary heart disease. - Scandinavian Journal of Work Environment and Health 31(4): 291-199.

[38] Wu, H. C., Chen, H. C., Chen, T. (2009): Effects of ergonomics-based wafer-handling training on reduction in musculoskeletal disorders among wafer handlers. - International Journal of Industrial Ergonomics 39(1): 127-132.

[39] Yildirım, M. (1989): Work Study and Planning. - Publication of the Faculty of Forestry Istanbul University, Pub. No:3556, Taş Matbaası, İstanbul, Turkey (in Turkish). 